\title{
Green approach for the synthesis and characterization of $\mathrm{ZrSnO}_{4}$ nanopowder
}

\author{
Taimur Athar ${ }^{1} \cdot$ Sandeep Kumar Vishwakarma ${ }^{2}$ Avinash Bardia ${ }^{2}$. \\ Razzaq Alabass $^{1} \cdot$ Ahmed Alqarlosy $^{1}$ - Aleem Ahmed Khan ${ }^{2}$
}

Received: 1 June 2015/Accepted: 5 August 2015/Published online: 14 August 2015

(c) The Author(s) 2015. This article is published with open access at Springerlink.com

\begin{abstract}
Well-defined structural framework of $\mathrm{ZrSnO}_{4}$ nanopowder has been synthesized for the fabrications of cost-effective and sensitive devices which give final reproducible result with reliability under ideal conditions. The synthesis was carried out at moderate temperature and then finally dried in the laboratory oven and then followed with calcination at $1000{ }^{\circ} \mathrm{C}$ for $4 \mathrm{~h}$ to get phase selective product. It was observed that gelation time depends on the concentration of reactants and temperature. The characterization of $\mathrm{ZrSnO}_{4}$ was carried out with XRD, SEM, TEM, UV, thermal analysis, DLS and FT-IR techniques. With adjustment of reaction parameters, the systematic tuning of the particle size, shape and functional properties can be controlled. It was concluded that self-assembly is an integral part for the synthesis and opens a new exciting opportunity for better understanding the formation of nanostructure framework from micro- to nanoscale along with mechanistic via wet chemical approach. $\mathrm{ZrSnO}_{4}$ has vital role in identifying its potential cytotoxicity in the biological systems. The cytotoxicity effects of $\mathrm{ZrSnO}_{4}$ nanopowder in vitro were evaluated in three different human cell types (hepatocytes, mesenchymal stem cells and neuronal cells). Acute exposure of nanoparticles was found to have greater cytotoxic effect at higher concentration $(30 \mu \mathrm{g} / \mathrm{ml})$. However, partial detoxification was observed during nanoparticles exposure
\end{abstract}

Taimur Athar

taimurathar2001@gmail.com

1 OBC, CSIR-Indian Institute of Chemical Technology, Hyderabad 500007, Andhra Pradesh, India

2 Salar-E-Millat Research Centre and Central Laboratory for Stem Cell Research and Translational Medicine, Centre for Liver Research and Diagnostics, Deccan College Medical Sciences, Hyderabad, Andhra Pradesh, India at day 6. The study concluded that an initial stress from nanoparticles incorporates sealing or detoxification of nanoparticles which may help to recover cell viability.

Keywords Green process $\cdot$ Microstructure $\cdot$ Particle size and its distribution $\cdot$ Cytotoxicity $\cdot$ Pre-screening tests

\section{Introduction}

Soft chemical approach is used extensively for preparation of metal oxide materials from molecular precursor by condensation and hydrolysis reactions. With the help of controlled parameters, a specific shape granulometry with high surface area can be achieved which depends on concentration of synthon in ionic solvent and temperature. Metal oxide nanopowder has important functional properties which can be utilized in wide range of applications for nanodevices due to their quantum size effects, surfacevolume ratio and nucleation having a favorable growth process. The fundamental properties depend on its architectural framework with required geometry, surface morphology, activity, selectivity and stability, and help to better understand the role of chemical composition, calcinations temperature and crystalline phase (Livage et al. 1998; Jolivet 2000; Fedlheim and Foss 2001; Schaf et al. 2002; Koch 2002; Marzan and Kamat 2003; Yang 2003; Mathur et al. 2004; Cao 2004; Fierro 2005; Mozetic et al. 2005; Rodriguez and Garcia 2007; Bandyopadhyay 2007; Muller et al. 2007; Vollath 2008; Naumann 2009; Lalena and Cleary 2010; Klabunde and Richards 2012). The presence of $\mathrm{M}-\mathrm{Cl}$ bond polarities acts as a molecular single source precursor to synthesize colloidal monodispersable nanopowder. The morphology of $\mathrm{ZrSnO}_{4}$ depends on the $\mathrm{pH}$ value of the reaction medium, nucleation, concentration 
of ionic solvents and temperature. The size and shape depend on atomic radius, coordination number of the metal ion and its degree of polarization solubility and volatility. Bimetallic oxide exhibits novel physico-chemical properties that can be tailored with composition, size and atomic ordering. Metal ion plays a crucial role in balancing the thermodynamic-kinetic parameters to control functional behavior due to its coordination with metal ions and also tuning of surface morphology leads to the formation of nanostructure material with high performance (Klein 1988; Brinker and Scherer 1990; Kessler 2003; Sakka 2004; Szafert et al. 2008; Bilecka and Niederberger 2010; Hassan et al. 2012; Precht and Campbel 2013; An and Soorrjai 2015). During synthesis, we focused the phase separation with non-aggregated particles by retaining stoichiometric ratio under control. The soft chemical process is flexible, simple and novel for the preparation of homogenous, welldispersed colloidal nanomaterials at the bench scale and then processing it to a production level, which help in fundamental studies based on structural and functional activities to design a nanodevice. Bimetallic metal oxide has growing demands in industrial and biomedical applications. There is great demand to investigate the toxicological effects and the development of its early toxicity detective indicators in human cells. In the present study, two different parameters [relative cell viability and lactate dehydrogenase (LDH) activity] were undertaken to determine the changes in cell membrane integrity and function. The cell proliferation assay provides overall activity of cells as an indicator for cellular stress, cytotoxic effects, changes in cell metabolism and relative cell viability. LDH activity provides information about cell membrane integrity after treatment with $\mathrm{ZrSnO}_{4}$ nanoparticles within 3-6 days. 3-day exposure time was selected to investigate the acute effect of $\mathrm{ZrSnO}_{4}$ nanoparticles exposure on cells whereas 6 days were used to assess the long-term effect.

\section{Experimental}

\section{Materials}

Zirconium oxychloride octahydrated, stannous chlorides dihydrate and solvents were purchased from SIGMA Aldrich and used as such without further purification. Deionized water with an electrical resistivity of $18 \mathrm{M} \Omega \mathrm{cm}^{-1}$ (Millipore, India) was used in the reaction.

\section{Characterization}

FT-IR spectra were recorded in the range of $4000-400 \mathrm{~cm}^{-1}$ using $\mathrm{KBr}$ pellets in Perkin Elmer GX spectrometer with a wave number resolution of $4 \mathrm{~cm}^{-1}$. The optical properties were recorded using GBC UV-Vis Cintra spectrophotometer with wavelength ranging from 200 to $800 \mathrm{~nm}$. Thermal analysis was carried out by heating the sample at the rate of $10{ }^{\circ} \mathrm{C} / \mathrm{min}$ from ambient to $1000{ }^{\circ} \mathrm{C}$ in dry air using Mettler Toledo star analyzer. X-ray powder diffraction patterns were taken in reflection mode of $\operatorname{CuK}_{\alpha}(\lambda=1.5406 \AA)$ radiation from $0 \theta$ to $80 \theta$ on a Siemens D5000 X-ray diffractometer using continuous diffraction. Scanning microscopy image was taken using Hitachi S520 scanning electron microscope. Philips Tecnai $\mathrm{G}^{2}$ FEI F12 transmission electron microscope was operated at $80-100 \mathrm{kV}$. The samples were collected on a carbon holey copper grid to see morphology and particle size. Raman spectra were obtained using RAM HR visible single spectrometer equipped by microscope and Peltier cooled CCD detector. The 633-nm He-Ne loose line was used for excitation. The multi-point BET was acquired on QuadraSorb Station 3 under nitrogen atmosphere after degassing the sample at $200{ }^{\circ} \mathrm{C}$ for an hour. DLS and laser Doppler velocimetry were used for characterization of particle size and zeta potential in solution using Malvern Instruments Zetasizer Nano-ZS instruments equipped with 4-mW He-Ne Laser $\theta=632.8 \mathrm{~nm}$.

\section{Synthesis}

Colloidal and monodisperable $\mathrm{ZrSnO}_{4}$ was synthesized via chemie-douce. The $\mathrm{ZrOCl}_{2} \cdot 8 \mathrm{H}_{2} \mathrm{O}(5.01 \mathrm{~g}, 15.53 \mathrm{mmol})$ and $\mathrm{KOH}(1.96 \mathrm{~g}, 34.94 \mathrm{mmol})$ were taken in $15-\mathrm{ml} \mathrm{de}-$ ionized water and heated with stirring from 25 to $80^{\circ} \mathrm{C}$ for $6 \mathrm{~h}$. The change in color takes place from dark green to light green at $\mathrm{pH}$ 10.5. The flask was cooled to room temperature,

$$
\begin{aligned}
& \mathrm{ZrOCl}_{2 .} 8 \mathrm{H}_{2} \mathrm{O}+2.25 \mathrm{KOH} \longrightarrow \mathrm{ZrO}(\mathrm{OH})_{2}+2 \mathrm{KCl}+8 \mathrm{H}_{2} \mathrm{O} \\
& \mathrm{SnCl}_{2} \cdot 2 \mathrm{H}_{2} \mathrm{O}+\mathrm{ZrO}(\mathrm{OH})_{2} \longrightarrow \mathrm{ZrO}_{2} \mathrm{Sn}(\mathrm{HO})_{2}+2 \mathrm{HCl}+\mathrm{H}_{2} \mathrm{O} \\
& \mathrm{ZrO}_{2} \mathrm{Sn}(\mathrm{HO})_{2}+2 \mathrm{HCl}+\mathrm{H}_{2} \mathrm{O} \stackrel{\text { Refluxed }}{\longrightarrow} \mathrm{ZrO}_{2} \mathrm{SnO}_{2}+\mathrm{H}_{2}
\end{aligned}
$$

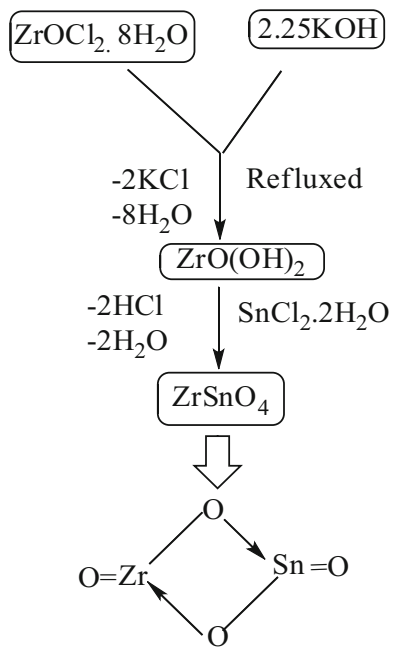

A graphical stretch of the reaction 
followed by the addition of $\mathrm{SnCl}_{2} \cdot 2 \mathrm{H}_{2} \mathrm{O}$ (3.51 g, $15.53 \mathrm{mmol}$ ) and again refluxed for $6 \mathrm{~h}$ with stirring. The reaction was monitored with the help of $\mathrm{pH}$. When the $\mathrm{pH}$ was 7.5 , it was filtered and a crystalline white power was obtained after several washing with de-ionized water. After calcinations, the light green powder was obtained.

\section{Cytotoxicity assessment}

Cytotoxicity effects of $\mathrm{ZrSnO}_{4}$ nanopowder were tested in three different cells; human hepatocytes, human mesenchymal stem cells (hMSCs) derived from umbilical cord blood and human neuronal cells.

Cell proliferation was measured as total metabolic activity using 3-(4,5-dimethylthiazol-2-yl)-2,5-diphenyltetrazolium bromide (MTT) test where selective conversion of yellow MTT occurs into purple formazan crystals after cellular metabolism. Lactate dehydrogenase (LDH) activity was measured with the help of colorimetric method to observe quantitative release of $\mathrm{LDH}$ into the medium from damaged cells and used as a predictor of cytolysis.

\section{Cell proliferation assay}

All the three types of human cells (hepatocytes, neuronal cells and MSCs) were cultured in 96-well plates at $2 \times 10^{4}$ cells/well as previously described (Vishwakarma et al. 2013a, b, 2014). Cells were maintained in the appropriate culture medium at $37{ }^{\circ} \mathrm{C}, 95 \%$ humidity and $5 \% \mathrm{CO}_{2}$. Cells without nanoparticles were considered as control. Cellular proliferation was measured using MTT cell proliferation assay as described in our previous study (Athar et al. 2015). Briefly, cells were mixed with three different concentrations of $\mathrm{ZrSnO}_{4}$ nanoparticles and maintained under standard culture conditions as described above. Each variable was kept in triplicate for 3-6 days. At day 3 and 6, $50 \mu \mathrm{l}$ of $1 \mathrm{mg} / \mathrm{ml}$ MTT was added and incubated for 4-5 h. After incubation, purple formazan crystals were dissolved using 100- $\mu$ l acidified Isopropanol and absorbance was measured at $570 \mathrm{~nm}$. Optical density (OD) values of each type of cells exposed to nanoparticles at day 3 and 6 were compared with control.

\section{LDH activity measurement}

$\mathrm{ZrSnO}_{4}$ nanoparticles cytotoxicity on membrane integrity was assayed by the amount of LDH released from dead cells using LDH assay kit (Promega) in all three types of cells individually. The assay was performed as per the manual of the kit. Briefly, $2 \times 10^{4}$ viable cells were incubated with $100 \mu \mathrm{l}$ of $\mathrm{ZrSnO}_{4}$ nanoparticles (10-30 $\mu \mathrm{g}$ / $\mathrm{ml}$ ) for 3-6 days in a 96-well plate. It was then mixed with $50 \mu \mathrm{l}$ of the reagent. The mixture was incubated for $30 \mathrm{~min}$ at room temperature. The reaction was stopped by adding $50 \mu \mathrm{l}$ of stop solution. Absorbance was measured at $490 \mathrm{~nm}$ using a microplate reader (BIORAD). Total cell lysate was used as positive control to assess the kit sensitivity for $100 \%$ with the release of $\mathrm{LDH}$ from the dead cells after incubation. All the variables were performed in triplicate to avoid any technical error. Mean value was calculated and plotted against the control.

\section{Morphological assessment}

Morphological analysis of all three types of cells was performed at day 3 and 6 using inverted confocal microscopy (Carl Ziess, Germany). A change in cellular

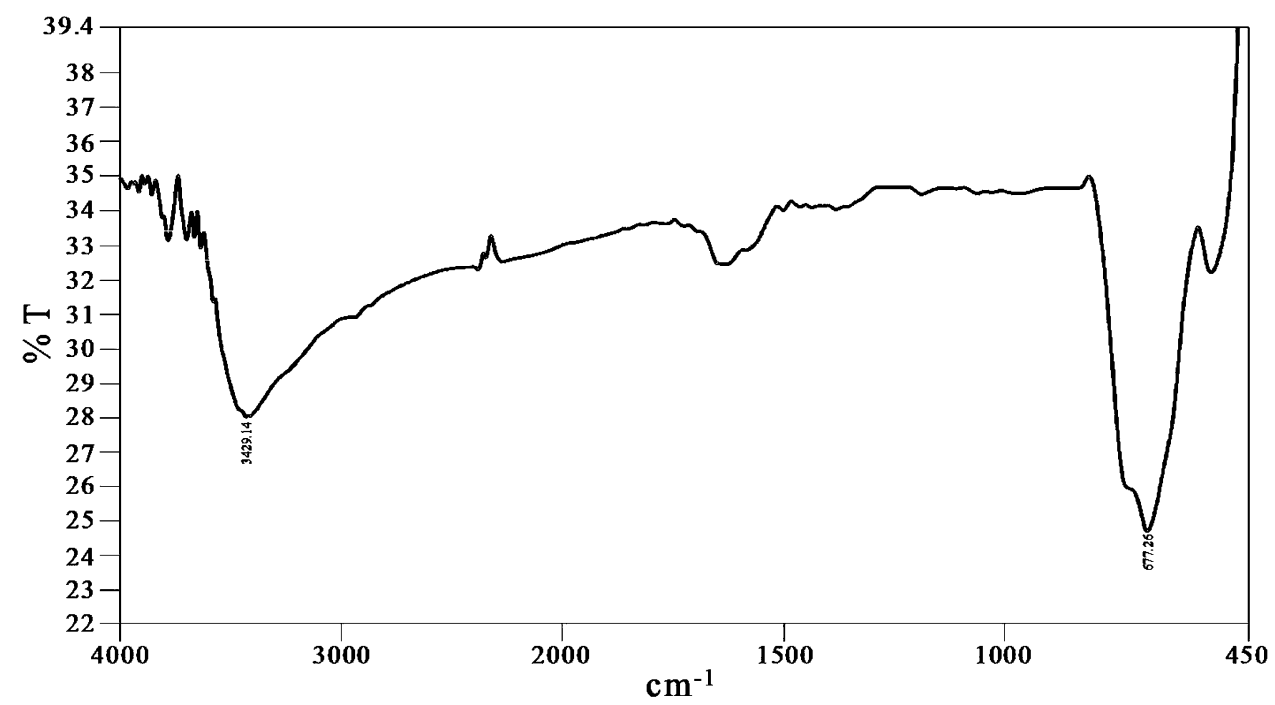

Fig. 1 FT IR studies of $\mathrm{ZrSnO}_{4}$ 


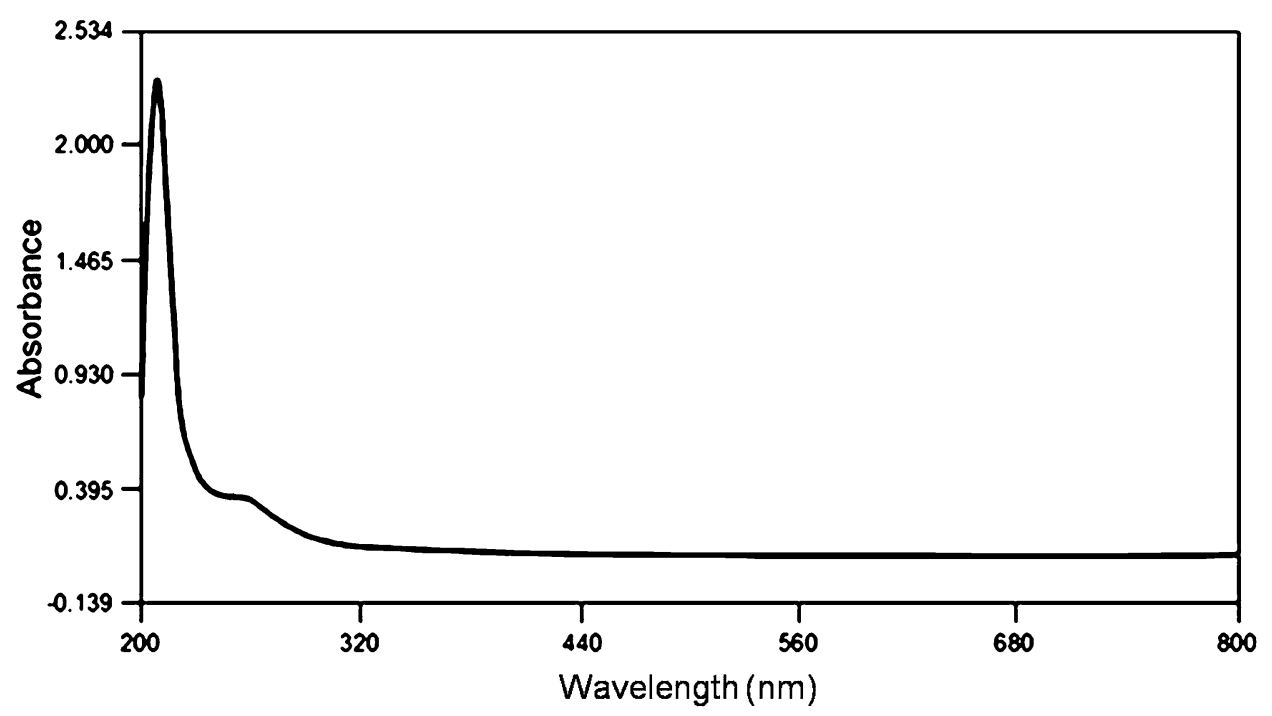

Fig. 2 UV studies of $\mathrm{ZrSnO}_{4}$

morphology was compared with control and nanoparticletreated cells using scale bar. Cellular stress was measured by counting the number of apoptotic bodies formed in each type of cell incubated with $\mathrm{ZrSnO}_{4}$ nanoparticles for different time points.

\section{Statistical analysis}

Mean value was calculated for each variable and compared with the control. Multiple comparison tests were performed using Graph Pad Prism (Version V). $p<0.05$ was set as significant value for all the variables.

\section{Results and discussion}

Synthesis of bimetallic oxide nanostructure powder is challenging due to the presence of two different metal ions which exhibit unique properties. The functional properties can be tuned by modifying the size, shape and composition of the synthon along by studying state of art of the synthetic method with $\mathrm{pH}$ control which helps to design a device for their technological applications with synergic effects to control the nucleation and its growth. Understanding the nucleation and growth process by self-assembling helps to integrate functional structures via optimizing hydrolysis and kinetic process based on electro-negativity of metal ion (Klein 1988; Brinker and Scherer 1990; Sakka 2004; Szafert et al. 2008; Grado-Caffaro 2008; Bilecka and Niederberger 2010; Bang and Suslick 2010; Liu et al. 2011; Hassan et al. 2012; Precht and Campbel 2013; An and Soorrjai 2015).

\section{FT-IR studies}

The bands become stronger on annealing, supporting the formation of a strong $\mathrm{Sn}-\mathrm{O}-\mathrm{Zr}$ framework after the removal of surface impurities. The occurrence of absorption band at $677.26,533.16$ and $509.13 \mathrm{~cm}^{-1}$ takes place due to $\mathrm{Zr}-\mathrm{O}-\mathrm{Sn}, \mathrm{Zr}-\mathrm{O}$ and $\mathrm{Sn}-\mathrm{O}$ band thereby supporting the formation of nanomaterials. The peaks at 3429.14 and $1667.12 \mathrm{~cm}^{-1}$ occur due to the vibration and deformation frequency of $\mathrm{OH}$ group which absorb water during sample preparation. With the help of synthetic approach, the crystalline nature takes place due to intermolecular forces as supported by thermal analysis and XRD studies. No change in vibration frequencies takes place even after aging, which support the quantum size particle to remain under control without any change in oxidation state of the metal ion (Fig. 1) (Little 1966; Sadtler Research Lab 1976; Nakamoto 1997; Smith 1999; Soacrates 2001; Stuart 2004; Pavia et al. 2009).

\section{UV studies}

The UV-visible spectra were recorded in $\mathrm{MeOH}$ to investigate their electronic properties. The optical property, purity and crystallinity of bimetallic powder were studied using UV-visible spectroscopy. The excitonic absorption band at $215,235 \mathrm{~nm}$ and the broad transmittance peak at $285 \mathrm{~nm}$ can be assigned to $\pi-\pi^{*}$ and $\pi-\rho$ bathochromic shift which support the formation of monodisperable colloidal nanostructured particle framework due to its quantum size effect and self-controlled surface morphology to enhance functional properties based on kinetic and thermodynamic stability. The bathochromic shift occurs due to 
the lone pair of electron on oxygen between two different metal ions which help to stabilize the electronic state towards the ground state which leads toward a long wavelength. High wavelength supports the formation of crystalline powder and decreases in grain size. This occurs due to change in quantum size and single ionized oxygen vacancy. The expansion and contraction in transmittance band lead to the formation of crystalline nature with aggregation of primary particle and chemical composition. It can be assumed that strain and surface defects occur due to absorption which has a tendency to absorb the energy difference between the conduction and valence bands in calcined powder. With an increase in particle size, the shifting of band gap takes place towards long wavelength with the reduction of forbidden band as shown in Fig. 2 (Daniel and Bertolucci 1989; Atkins and Paula 2006; Pavia et al. 2009).

\section{Raman studies}

Raman study reveals the interaction of metal domain within nanostructure framework along with grain size. It is assumed that the characteristic active modes occur due to tetragonal structure. The Raman active modes were assigned at $153.4 \mathrm{~cm}^{-1}\left(\mathrm{~B}_{1 \mathrm{~g}}\right), 194 \mathrm{~cm}^{-1}\left(\mathrm{E}_{1 \mathrm{~g}}\right), 294 \mathrm{~cm}^{-1}$ $\left(E_{2 g}\right), 350 \mathrm{~cm}^{-1}\left(E_{2 g}\right), 400 \mathrm{~cm}^{-1}\left(A_{1 g}\right), 500 \mathrm{~cm}^{-1}\left(A_{2 g}\right)$ and $660 \mathrm{~cm}^{-1}\left(\mathrm{~B}_{2 \mathrm{~g}}\right)$. The decrease in crystallite size takes place with an increase in broad intensity in all active modes. It was observed that Raman active modes take place below $1500 \mathrm{~cm}^{-1}$ as shown in Fig. 3 (Nakamoto 1997; Soacrates 2001). The change in frequencies shifts with a broadening of peaks which can be attributed with an increase in particle size.

\section{XRD studies}

XRD spectra show strong diffraction peaks which confirm the formation of bimetallic oxide nanopowder with orthorhombic shape. The crystalline shape with characteristic peaks was assigned at $2 \theta=26,30,33.5,50,52,60$ and 62. The values match with the PDF No.; 79-1769, 65-2357, 88-0287, 48-0884. The particle size calculated with broad full half width maxima indicates the formation of particle size in range of $61.89 \mathrm{~nm}$. After calcination, the size of crystalline particle increases with surface purity, chemical composition and phase purity. It can be
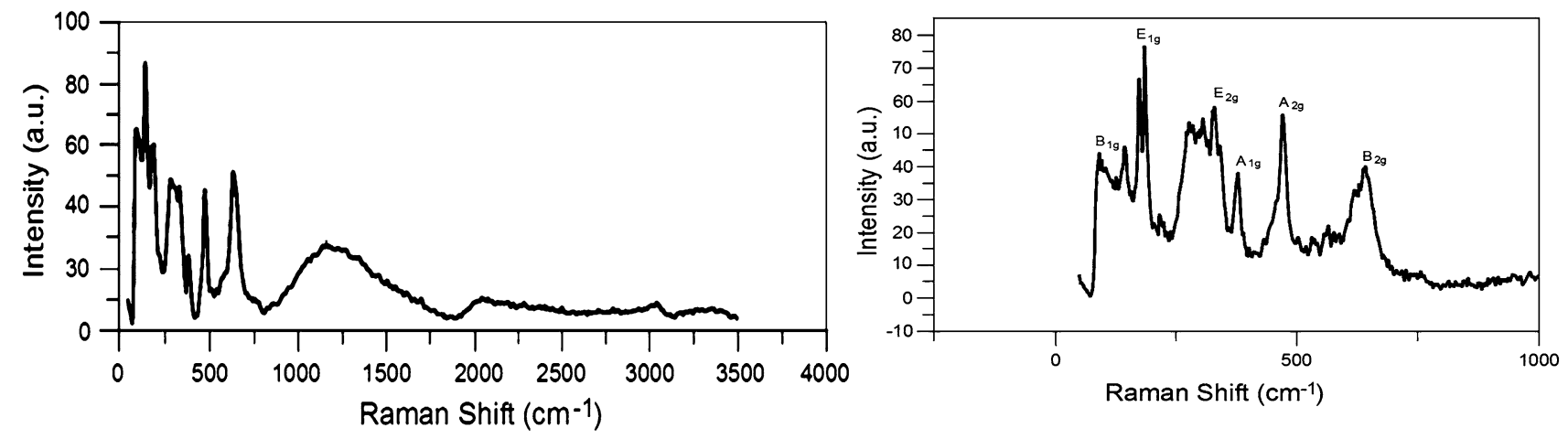

Fig. 3 Raman studies of $\mathrm{ZrSnO}_{4}$

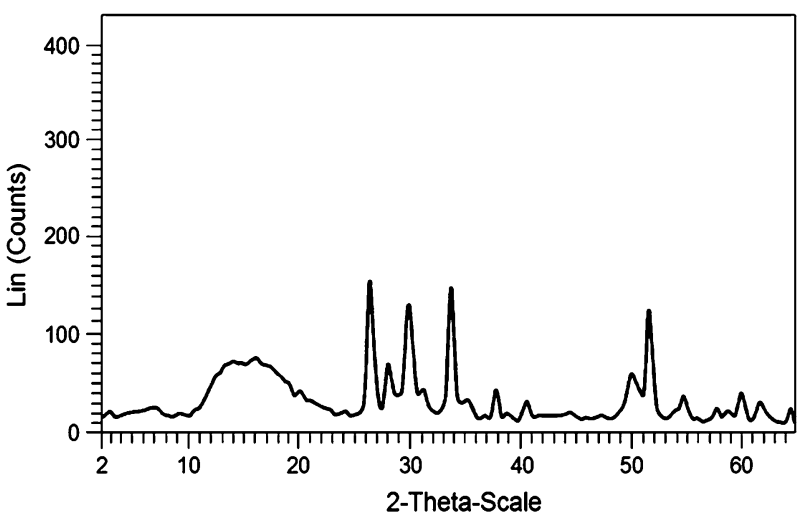

Fig. 4 XRD studies of $\mathrm{ZrSnO}_{4}$ 


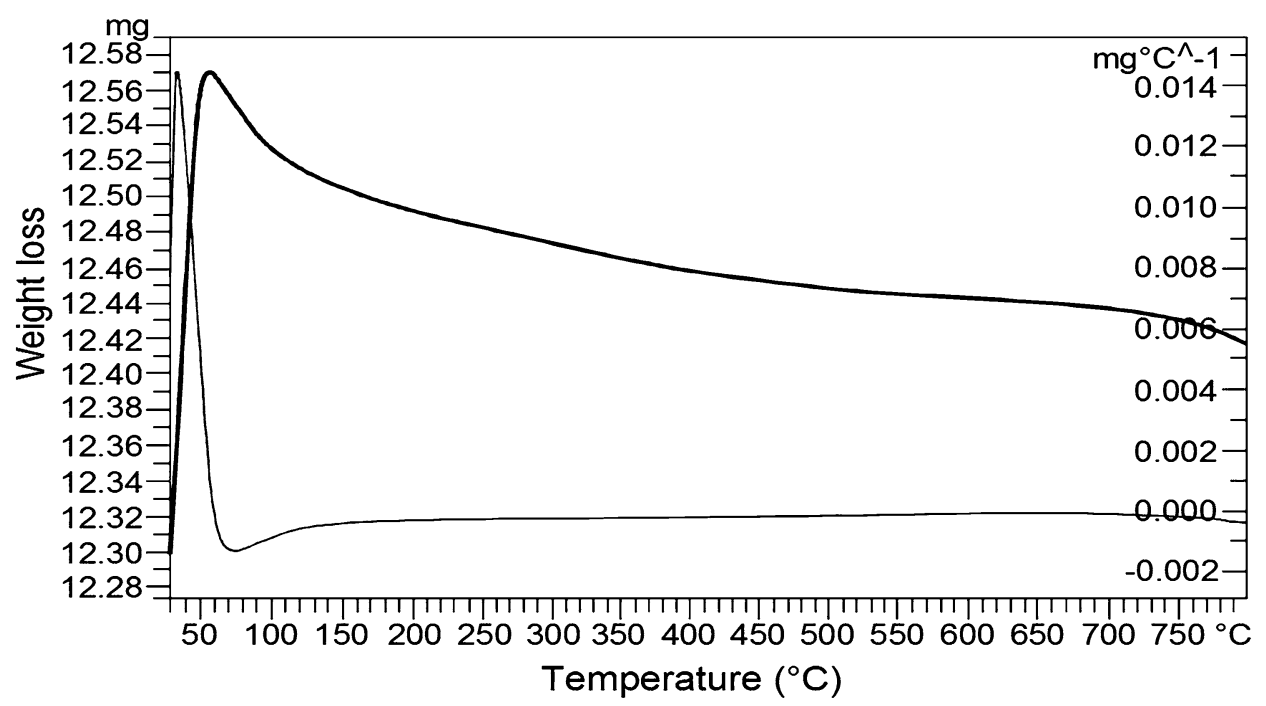

Fig. 5 Thermal studies of $\mathrm{ZrSnO}_{4}$

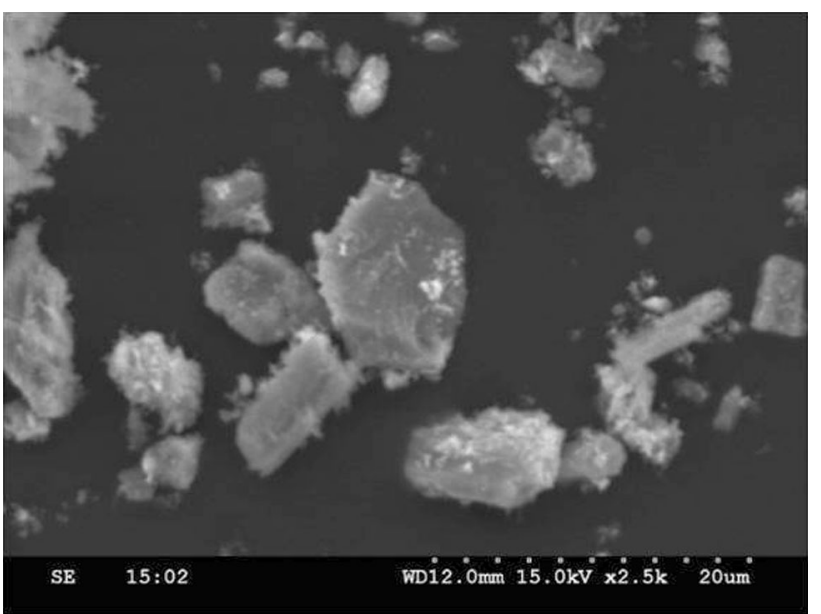

Fig. 6 SEM studies of $\mathrm{ZrSnO}_{4}$

concluded that the formation of crystalline phases depends on the types of molecular framework of the precursor, reaction time, temperature, solvent, and synthetic methodology along with their heating rate with type of molecular precursor used. It was observed that broadening of peak increases with temperature and its temporal stability of colloidal particle as shown in Fig. 4 (Klug and Alexander 1974; Cullity 1978; Guinier 1994; Skoog et al. 2007; Zeng and Ostwald 2007; Powder Diffraction Files JCPDS 1993).

\section{Thermal studies}

The thermal analysis was carried out to understand the changes taking place with phase purity after the removal of surface impurity, which help to build crystalline structure via self-assembly. The first step involves the removal of unbound water at $70-100{ }^{\circ} \mathrm{C}$ followed by removal of volatile materials from the particle surface, then finally leads to the formation of crystalline $\mathrm{ZrSnO}_{4}$ nanoparticle with phase purity as illustrated by a presence of an endothermic peaks. The exothermic peak at $90{ }^{\circ} \mathrm{C}$ refers to the phase purity after removal of surface impurities resulting in the formation of crystalline state at $250{ }^{\circ} \mathrm{C}$ (Fig. 5) (Watt 1997; Davydov 2003; Gabbott 2007; Niasaria et al. 2009).

\section{SEM studies}

SEM images show the presence of irregular tetragonal surface after calcinations at low magnification with porous structure having an irregular morphology due to condensation of different particle sizes to form nanocluster framework with the help of Ostwald ripening process. The particle morphology changes with reaction condition, time and synthetic approach. The formation of particle takes place with growth and with stabilization of nuclei along with the type of metal ions used in the framework as shown in Fig. 6 (Watt 1997; Davydov 2003; Gabbott 2007; Niasaria et al. 2009).

\section{TEM studies}

TEM exhibits colloidal stability with poly-dispersity due to aggregation and overlapping of small particles to form large particle. Some nanoplates formed due to integration of large particle confirm the interaction of small particle with limited uniformity which leads to the formation of mesovoids due to weak inter-intra particle forces due to defocusing process with the presence of high surface 


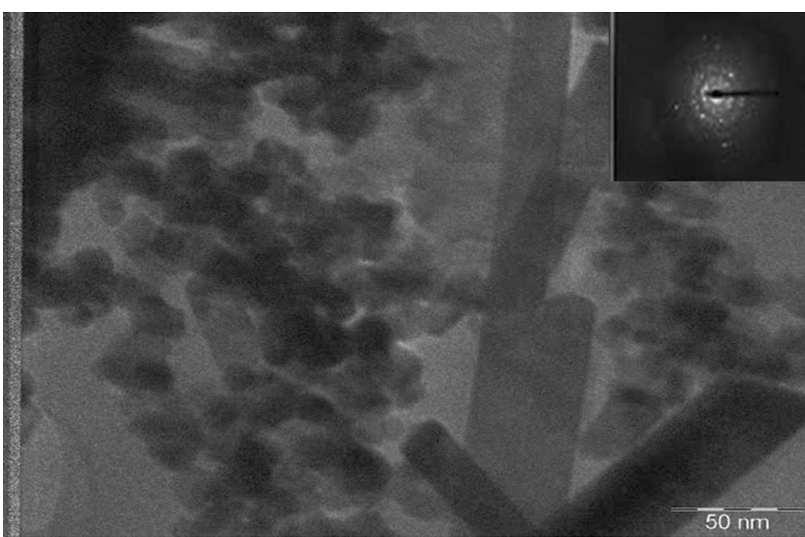

Fig. 7 TEM studies of $\mathrm{ZrSnO}_{4}$

energy. The SAED pattern supports the tetragonal structure with an intensity of peaks as supported by X-ray diffractogram with temperature. SAED shows the presence of distinct and good diffraction rings at different planes which support the presence of polycrystalline structure with narrow particle size distribution as observed from XRD studies as observed in Fig. 7 (Watt 1997; Mitra 2003; Williams and Carter 2010).

\section{BET studies}

The BET surface area was found to be $3.95 \mathrm{~m}^{2} / \mathrm{g}$, which supports the formation of crystalline structure with limited porosity.

\section{DLS studies}

The characteristic active modes may be assumed to be tetragonal structure. The presence of other additional bands can be assigned to the nanostructure crystal metal oxide framework. DLS measurement takes place due to fluctuation of light intensity with time due to random Brownian motion within nanoparticles which depend on particle size. The zeta studies were carried out for particle size and its distribution. The mean particle size diameter was found to be $190.1 \mathrm{~nm}$ with mean zeta potential which can be corelated with dispersion stability. The presence of negative charge indicates that the particle size is small in nanoscale as shown in Fig. 8 (Mitra 2003).

\section{Fluorescence studies}

The presence of broad excitonic peak at $440 \mathrm{~nm}$ with excitation intensity at 160 can be attributed with presence of nanostructure framework. The excitonic intensity varies with change in temperature. It seems that the change in intrinsic intensity of fluorescence remains constant with concentration. The presence of oxygen vacancies interacts with interfacial atoms of two different metal ions to give fluorescence studies as shown in Fig. 9.

\section{In vitro cytotoxicity data of $\mathrm{ZrSnO}_{4}$ nanoparticles}

Nanoparticles cytotoxicity needs in-depth investigations at physiologically relevant conditions. Therefore, the present study was carried out to investigate $\mathrm{ZrSnO}_{4}$ nanoparticles with acute and long-term cytotoxicity at different concentrations $(0-30 \mu \mathrm{g} / \mathrm{ml})$. Toxicity results are nearly the same for most investigated Zirconium compounds. The use of combination of cytotoxicity methods was found to be best tailored to deliver reliable data of nanoparticles biocompatibility. All the three cell types were capable of better dealing with $\mathrm{ZrSnO}_{4}$ nanoparticles when compared for 6 days in vitro exposure instead of 3 days. From these observations, it may be concluded that an initial stress from nanoparticle incorporates sealing/detoxification of nanoparticles which may help to recover cell viability. The sealing mechanism occurs with results obtained from detoxification assay and also previously reported by
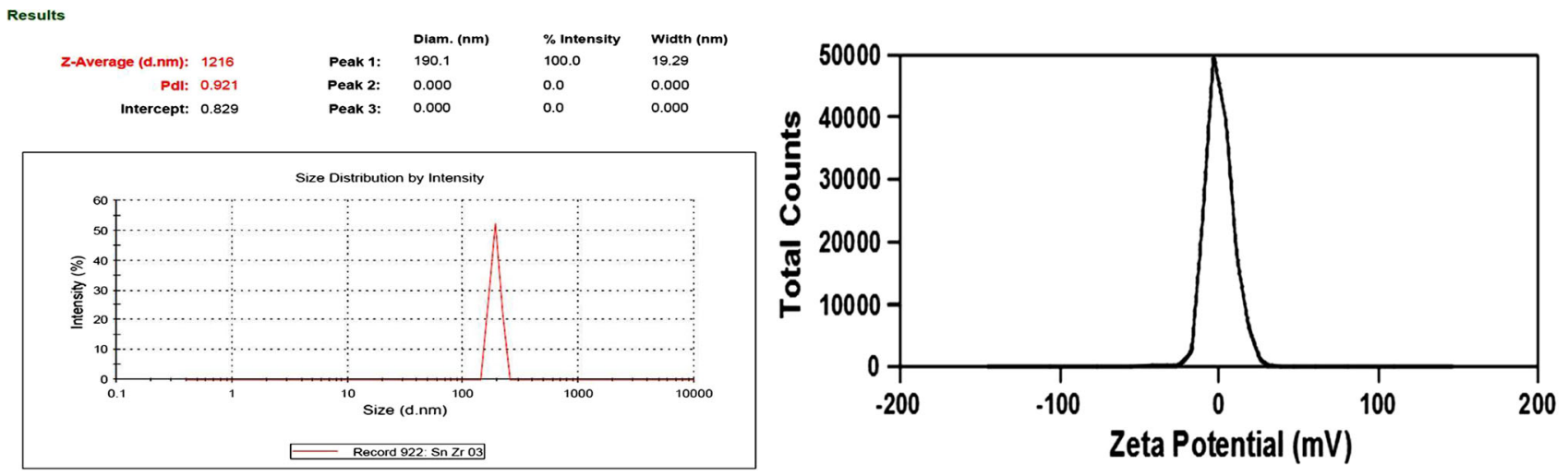

Fig. 8 DLS studies of $\mathrm{ZrSnO}_{4}$ 


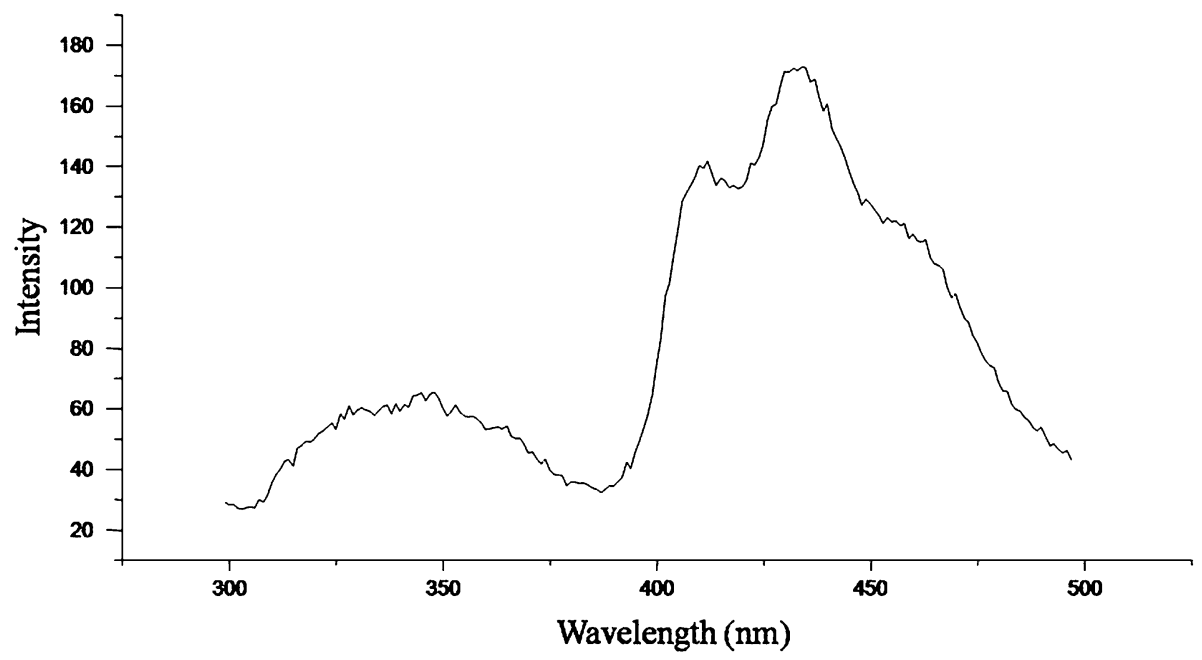

Fig. 9 The fluorescence studies of $\mathrm{ZrSnO} 4$ nanopowder show the emission peak at $440 \mathrm{~nm}$ due to oxygen
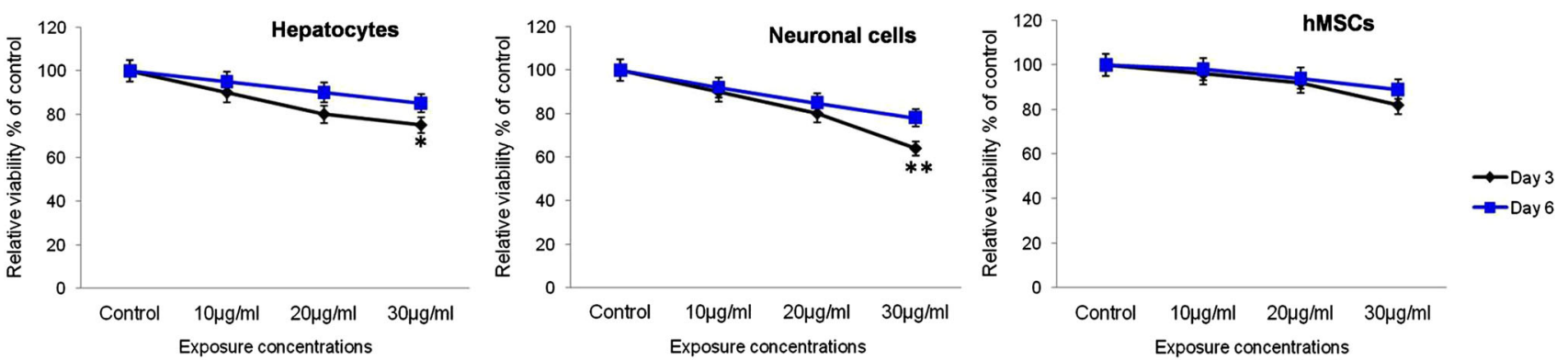

Fig. 10 MTT cell proliferation assay showing relative percentage viability of controls in human hepatocytes, neuronal cells and MSCs incubated with different concentrations of $\mathrm{ZrSnO}_{4}$ nanoparticles for 3-6 days

Limbach et al. (2005) where they found that cells incorporate the ceria nanoparticles into vesicles. Formation of apoptotic bodies occurs due to nanoparticles acute exposure as shown in Fig. 12, presumed that it contains part of the absorbed nanomaterials and is in agreement with the mechanism where cells exclude the toxic intruders. The recovery in cellular phenotype and viability showed high concentration-dependent sensitivity and was found for 3 - to 6-day exposure. Among the three cell types used in the study, neuronal cells were found more sensitive for the $\mathrm{ZrSnO}_{4}$ nanoparticles whereas hMSCs were least affected cell type. However, there was no significant difference observed among the cytotoxicity data on different cell types.

\section{Relative cell viability during proliferation}

After 3 days, the effect of $\mathrm{ZrSnO}_{4}$ nanoparticles on all three cell types' cultures showed a comparable response where the cell parameter values were constitutively affected with increase in nanoparticles concentrations (Fig. 10). Cellular proliferation was significantly reduced during incubation for 3 days, but was not entirely killed at high concentrations $(30 \mu \mathrm{g} / \mathrm{ml})$. Exposure of nanoparticle for 6 days showed recovery in cellular proliferation as compared to day 3 . The increase in absorbance represents that cells start to recover from stress produced by nanoparticles exposure (Fig. 10). Neuronal cell proliferation was found comparatively most affected cell type during exposure to nanoparticles with increasing concentrations. However, human MSCs were least affected cells during exposure to $\mathrm{ZrSnO}_{4}$ nanoparticles.

\section{Relative cytolysis/cell membrane integrity}

Relative cytolysis was measured with an amount of LDH released from dead cells in all three cell types tested using LDH assay kit (Promega WI). Figure 11 represents an increase in cytolysis after 3 days with increasing concentrations of $\mathrm{ZrSnO}_{4}$ nanoparticles. After 6 days, reduced level of released LDH was observed as compared to day 3 . Neuronal cells were found to release more LDH as compared to other two cell types during $\mathrm{ZrSnO}_{4}$ nanoparticles 

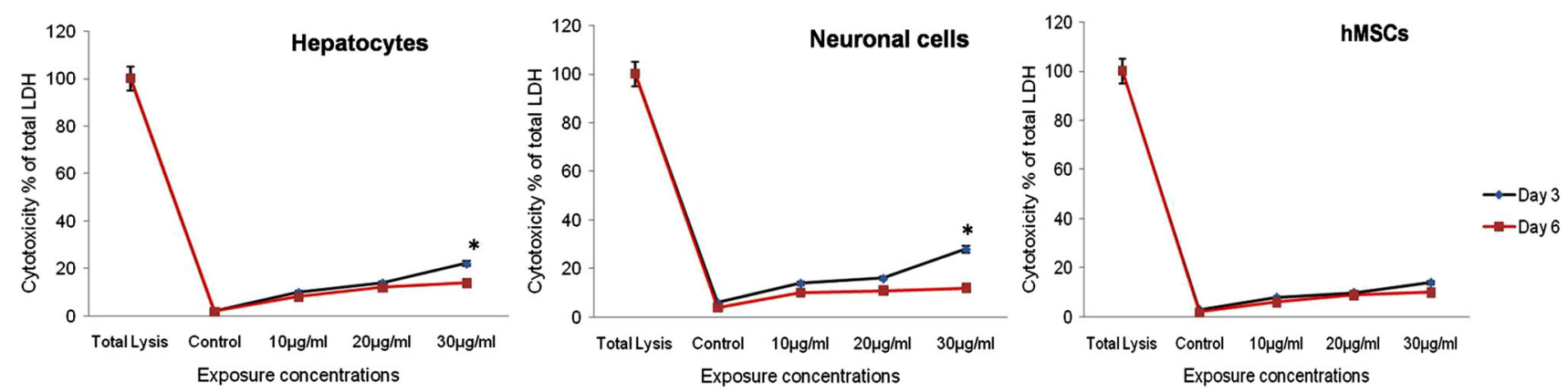

Fig. 11 Cytotoxicity measurement based on the quantity of LDH released from hepatocytes, neuronal cells and MSCs after incubation for 3-6 days with different concentrations of $\mathrm{ZrSnO}_{4}$ nanoparticles
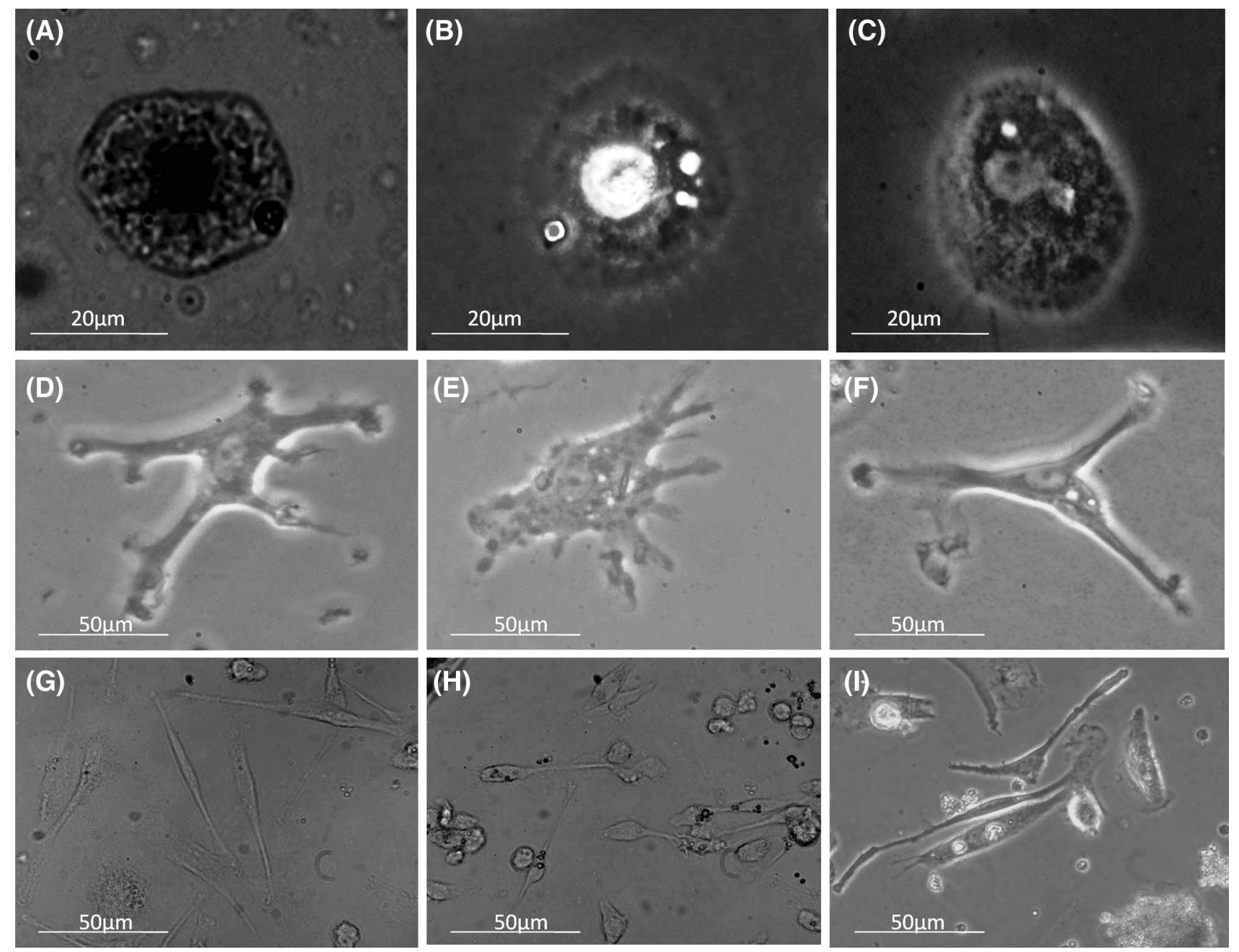

Fig. 12 Morphological changes in cultured human hepatocytes, neuronal cells and MSCs after 3- to 6-day incubation: a control hepatocytes without treatment; b $30 \mu \mathrm{g} / \mathrm{ml} \mathrm{ZrSnO}_{4}$ nanoparticles treated hepatocytes after 3 days and c 6 days. d Neuronal cells without nanoparticles exposure, e neuronal cells exposed to $30 \mu \mathrm{g} / \mathrm{ml}$
$\mathrm{ZrSnO}_{4}$ nanoparticles for 3 days and f 6 days. g hMSCs without nanoparticles exposure, h hMSCs exposed to $30 \mu \mathrm{g} / \mathrm{ml} \mathrm{ZrSnO}_{4}$ nanoparticles for 3 days and i 6 days. Probably apoptotic bodies within the cell represent stress produced due to nanoparticles acute and chronic exposure 
exposure. $100 \%$ lysed cells were used in respective studies as a positive indicator to measure the cytolysis/LDH release from each type of cell.

\section{Morphological changes attributable to $\mathrm{ZrSnO}_{4}$ nanoparticles exposure}

All the three cell types were found to have minor effect of $\mathrm{ZrSnO}_{4}$ nanoparticles on their shape and size.

\section{Human hepatocytes}

Figure 12a represents normal growing oval-shaped hepatocytes without nanoparticles exposure during in vitro culture. However, after 3 days incubation with $30 \mu \mathrm{g} / \mathrm{ml} \mathrm{ZrSnO}_{4}$ nanoparticles, slight morphological change was observed with nearly spherical shape with increase in volume, and loss of adhesion in the cell culture plate as shown in Fig. 12b. Which was returned to its normal shape at day 6 and showed a lesser amount of cell death and enhanced adherence (Fig. 12c). Very less number of apoptotic bodies was observed in very few cells at day 6 as compared to day 3 .

\section{Human neuronal cells}

Neuronal cells were found to have most severely affected cells during $\mathrm{ZrSnO}_{4}$ nanoparticles exposure with increasing concentrations. Figure 12d demonstrates human neuronal cell with normal morphology without nanoparticles exposure. However, Fig. 12e clearly demonstrated that exposure of $30 \mu \mathrm{g} / \mathrm{ml} \mathrm{ZrSnO}_{4}$ nanoparticles to developing neurons affects the cell phenotype. Reduced cell size with least dendrites and more apoptotic bodies were observed at day 3 which was later found to be recovered till certain extent at day 6 (Fig. 12f).

\section{Human MSCs}

MSCs were least affected cells on exposure to $30 \mu \mathrm{g} / \mathrm{ml}$ $\mathrm{ZrSnO}_{4}$ nanoparticles during in vitro culture for 3-6 days. However, formation of apoptotic bodies greatly enhanced at day 3 during nanoparticles exposure with slight change in morphology from flattened to condensed (Fig. 12h). Morphological improvement was further observed at day 6 with increased size and presence of least apoptotic bodies (Fig. 12i).

\section{Conclusions}

Cost-effective soft chemical synthesis offers a high degree of flexibility with desired size, shape and morphology by retaining the stoichiometric ratio under control. High zeta potential value supports the stabilization of synthesized metal oxide nanopowder with crystallinity and porosity to fabricate a device for its future applications with high selectivity, reliability and reproducible results at the bench scale, so that it can be scale up for production. A good knowledge of particle size, shape and internal atomic ordering plays a crucial factor for exploiting the chemical and physical properties within $\mathrm{M}-\mathrm{O}-\mathrm{M}$ molecular framework with well-defined structural properties. The mechanistic approach helps for better understanding the design of hierarchical architecture which still remains a hot topic for understanding the functional properties.

The results showed that relatively simple cell culture of MTT conversion and LDH activity can be useful assays to characterize nanoparticles biocompatibility prior to their vivo exposure. The detailed investigations using advanced cell and molecular biological experiments help in better understanding of detailed cellular and molecular mechanism involved in interaction between different types of cells with nanoparticles.

Open Access This article is distributed under the terms of the Creative Commons Attribution 4.0 International License (http:// creativecommons.org/licenses/by/4.0/), which permits unrestricted use, distribution, and reproduction in any medium, provided you give appropriate credit to the original author(s) and the source, provide a link to the Creative Commons license, and indicate if changes were made.

\section{References}

An K, Soorrjai GA (2015) Nanocatalysis synthesis of metal and bimetallic nanoparticles and porous oxide and their catalytic reaction studies. Catal Lett 1(145):233-248

Athar T, Vishwakarma SK, Bardia A, Paspala SAB, Habeeb MA, Khan AA (2015) Soft chemical approach for the synthesis, characterization and safety assessment of novel Fe3AlO6 nanopowder in human neural precursor cells. J Bionanosci 9:135-144

Atkins P, Paula J (2006) Physical chemistry, 8th edn. Oxford University Press, New York

Bandyopadhyay AK (2007) Mathematical physics for engineers. Nanomaterials. New Age International, New Delhi

Bang HJ, Suslick KS (2010) Application of ultrasound to the synthesis of nanostructured materials. Adv Mater 22:1039-1059

Bilecka I, Niederberger M (2010) Microwave chemistry for inorganic nanomaterials synthesis. Nanoscale 2:1358-1374

Brinker CJ, Scherer GW (1990) Sol-gel science: the physics and chemistry of sol-gel processing. Academic Press, San Diego, p 108

Cao G (2004) Nanostructures and nanomaterials. Imperial College Press, London

Cullity BD (1978) Elements of X-ray diffraction. Addison-Wesley Publishing Company Inc, London

Daniel H, Bertolucci Michael B (1989) Symmetry and spectroscopy. An introduction to vibrational and electronic spectroscopy. Dover Publications Inc, New York

Davydov A (2003) Molecular spectroscopy of oxide for catalyst surface. Wiley, Chichester 
Fedlheim DL, Foss CA (2001) Metal nanoparticles. CRC Press, New York

Fierro JLG (2005) Metal oxide: chemistry and applications. Taylor \& Francis, New York

Gabbott P (2007) Principles and applications of thermal analysis. Wiley-Blackwell Publishing, USA

Grado-Caffaro MA (2008) A quantitative discussion on band-gap energy and carrier density of $\mathrm{CdO}$ in terms of temperature and oxygen partial pressure. Phys Lett A 372(27-28):4858

Guinier A (1994) X-ray diffraction in crystals, imperfect crystals and amorphous bodies. Dover Publications, New York

Hassan H, Zaki T, Mikhail S, Kandil A, Farag A (2012) Optimization of the synthesis of nanostructured Tungsten-Molybdenum bimetallic oxide. ISRN Nanomater 2012:1-14

Jolivet JP (2000) Metal oxide chemistry and synthesis: from solution to solid state. Wiley, Chichester

Kessler VG (2003) Molecular structure design and synthetic approaches to the heterometallic alkoxide complexes (soft chemistry approach to inorganic materials by the eyes of a crystallographer). Chem Commun 11:1213-1222

Klabunde KJ, Richards RM (2012) Nanoscale materials in chemistry, 2nd edn. Wiley, New York

Klein LC (1988) Sol-Gel technology for thin film, fibres, performs, electronic, and speciality shape. Noyes Publications, Park Ridge

Klug MP, Alexander LE (1974) X-ray diffraction procedure for polycrystalline and amorphous materials. Wiley, New York

Koch CC (2002) Nanostructured materials. William Andrew Publishing, New York

Lalena JN, Cleary DA (2010) Principles of inorganic materials design. Wiley, New York

Limbach LK, Li YC, Grass RN, Brunner TJ, Hintermann MA, Muller M, Gunther D, Stark WJ (2005) Oxide nanoparticle uptake in human lung fibroblasts: effects of particle size, agglomeration, and diffusion at low concentrations. Environ Sci Technol 39:9370-9376

Little LH (1966) Infrared spectra of absorbed species. Academic Press, New York

Liu J, Zhao C, Li Z, Yu L, Li Y, Gu S, Cao A, Jiang W, Liu J, Yang C (2011) Solid-state synthesis and optical properties-controlling studies of CdO nanoparticles. Adv Mater Res 228-229:580-585

Livage J, Henry M, Sanchez C (1998) Sol-gel chemistry of transition metal oxides. Prog Solid State Chem 18:259-341

Marzan LM, Kamat PV (2003) Nanoscale materials. Springer, Berlin

Mathur S, Shen H, Nalwa HS (2004) Inorganic nanomaterials from molecular templates. In: Encyclopedia of nanoscience and nanotechnology, vol 4, p 131-192

Mitra S (2003) Sample preparation techniques in analytical chemistry. Wiley, New Jersey

Mozetic M, Cvelbar U, Sunkara MK, Vaddiraju S (2005) Synthesis of large quantities of metal oxide nanowires at low temperature. Adv Mater 17:2138-2142

Muller A, Cheetham AK, Rao CNR (2007) Nanomaterials chemistry: recent developments and new directions. Wiley-VCH, Weinheim

Nakamoto K (1997) Infrared and Raman spectra of inorganic and coordination compounds, 5th edn. Wiley-Interscience, New York
Naumann RJ (2009) Introduction to the physics and chemistry of nanomaterials. CRC Press, Boca Raton

Niasaria MS, Mir N, Davar F (2009) Synthesis and characterization of $\mathrm{NiO}$ nanoclusters via thermal decomposition. Polyhedron 28(6):1111-1114

Pavia DLGL, Kriz GS, Vyvyan JR (2009) Introduction to spectroscopy, 4th edn. Brooks/Cole Cengage Learning, USA

Powder Diffraction Files JCPDS (1993) Ed: International Center for Diffraction Data, Pasadena, CA

Precht MHG, Campbel PS (2013) Metal oxide and bimetallic nanoparticles in ionic liquids: synthesis and application in multiphase catalyst. Nanotechnol Rev 2(5):577-595

Rodriguez JA, Garcia MF (2007) Synthesis, properties and application of oxide nanomaterials. Wiley, Hoboken

Sadtler Research Lab (1976) Inorganic IR spectra. Sadtler Research Lab, Philadelphia

Sakka S (2004) Hand book of Sol-gel science and technology: processing, characterization and applications. Kluwer Academic Publishers, Norwell

Schaf O, Ghobarker H, Knauth P (2002) Nanostructured materials, selected synthesis methods properties and applications. Kluwer Academic, Norwell

Skoog DA, Holler FJ, Crouch SR (2007) Principles of instrumental analysis, 6th edn. Thomson Brooks/Cole, Belmont 169

Smith B (1999) Infrared spectral interpretation: a systematic approach. CRC Press, Boca Raton

Soacrates G (2001) Infrared and Raman characteristic group frequencies: tables and charts. Wiley, Chichester

Stuart HB (2004) Infrared spectroscopy fundamentals and applications. Wiley, Chichester

Szafert S, Utko JL, Sobota P (2008) Well defined polynuclear heterometallic complexes as precursors for ceramic and magnetic materials. Dalton Trans 46:6509-6520

Vishwakarma SK, Paspala SAB, Bardia A et al (2013a) Isolation and characterization of neural precursor cells from different regions of human fetal brain: assessment of in vitro proliferation and differentiation. Int J Adv Res 1:782-793

Vishwakarma SK, Khan MA, Bardia A, Tiwari SK, Khan AA (2013b) In vitro assessment of osteogenic and chondrogenic differentiation potential of human bone marrow derived mesenchymal stem cells. Int J Adv Res 1(10):157-164

Vishwakarma SK, Rahamathulla S, Bardia A, Tiwari SK, Srinivas G, Raj A, Tripura C, Sandhya A, Habeeb MA, Khan AA, Pande G, Reddy KP, Reddy PY (2014) In vitro quantitative and relative gene expression analysis of pancreatic transcription factors $\mathrm{Pdx}-$ 1, Ngn-3, Isl-1, Pax-4, Pax-6 and Nkx-6.1 in trans-differentiated human hepatic progenitors. J Diab Invest. doi:10.1111/jdi.12193

Vollath D (2008) Nanomaterials. Wiley, Weinheim

Watt IM (1997) The principles and practice of electron microscopy, 2nd edn. Cambridge University Press, Cambridge

Williams DB, Carter CB (2010) Transmission electron microscope: a textbook for material science. Springer, Berlin

Yang P (2003) The chemistry of nanostructured materials. World Scientific, Singapore

Zeng HF, Ostwald R (2007) A synthetic approach for hallow nanomaterials. Curr Nanosci 3:177-181 